\title{
Transgenic trials under pressure in Germany
}

Munich. Germany's largest environmental protection pressure group, BUND, has called for a ban on all field experiments with genetically-manipulated plants, following the publication of a report on experiments demonstrating the spontaneous transfer of a gene from a transgenic oilseed rape hybrid into a closely related weed-like plant.

The reaction to the results has put further pressure on German plant geneticists, who already experience a level of hostility to their field experiments not encountered in other countries. As a result, relatively little research in molecular plant genetics is carried out in Germany compared with other large European countries.

Scientists in Germany, as well as the authors of the paper published last week in Nature as an item of Scientific Correspondence (see Nature 380, 31; 1996), claim that environmentalists are deliberately misinterpreting the data to 'prove' a danger that the scientists deny exists.

The transgenic crop in question, Brassica napus, was modified to carry the gene which encodes the enzyme phosphinothricine acyltransferase, so conferring resistance to the herbicide glufonsinate which is sold in Europe under the name BASTA. The patent on the gene is owned by the German company AgrEvo.

The report shows that within a couple of growing seasons, the herbicide-resistant gene was able to transfer into $B$. campestris, the weed-like plant. The authors of the paper first crossed the oilseed rape carrying the herbicide tolerant gene with $B$. campestris. They then crossed these hybrids back with $B$. campestris. These new plants, which were stable and fertile, were found to contain the tolerance gene.

Thomas Mikkelsen, a research student at the Risø National Laboratory in Denmark,

\section{Europe 'sliding back' in technology}

London. A European Commission annual survey of industry has warned that the European Union (EU)'s declining share of patents - compared to Japan and the United States - could threaten its commercial competitiveness in fields where the EU currently enjoys "technological leadership".

The annual Panorama of Industry, published at the end of February, says the EU lost patent share "in all sectors" between 1984 and 1993 except aerospace and transport equipment. "The most worrying observation", says the report, "is the rapid further deterioration of the EU's already weak position in the electronics sectors", where research and development activity "is at its most intense at the world level”. who co-authored the report, says that such spontaneous gene transfer cannot be extrapolated to other transgenic crops, such as potatoes or maize, as they do not have close weedy relatives in Europe. In addition, crossbred plants, like crossbred animals such as the mule, are usually sterile.

But this has not stopped environmentalists from exploiting the publicity the report has prompted, with headlines claiming that 'superweeds' could soon overrun food crops. Senta Seip, a spokesperson for the Greens in Hessen, for example, said the results show "the risks of gene technology cannot be predicted", and "confirm the party's view that field trials with gene-manipulated rape should be abandoned".

Last year, all 15 small field trials conducted by universities and research institutes in Germany were partially or fully destroyed by activists, even though most were studying the environmental safety of growing genetically-manipulated plants in normal agricultural environments. Larger scale industrial field trials were also attacked, but suffered relatively fewer problems because the size of the fields makes them more difficult to destroy.

Gerhard Wenzel, a professor at the Technical University of Munich, runs a project funded by the Bavarian government's Forbiosich (safety in biotechnological research) programme to study the spread of the glufosinate gene from transgenic maize and rape through soil and via airborne pollen. Frustrated by repeated attacks on his crops, Wenzel wants the authorities to construct a fence around his field site south of Munich. But this has always been rejected, he says, on the grounds that it could disturb wildlife.

At the same time, Wenzel acknowledges that a security fence could provide environmental activists with ammunition for claims that transgenic crops are dangerous. Gerhard Waitz, a spokesman for AgrEvo, which last year lost two trials with glufosinate-resistant crops to activist attacks, says the company made a deliberate decision not to embark on security exercises. "If you want to sell a product, you cannot start by putting it behind fences," he says.

Other solutions are expensive. Detlef Barsch, a postdoctoral fellow from the University of Aachen who is heading a project on the environmental impact of virus-resistant sugar beet, was attacked with stones last year when trying to evict activists from a field site near the Dutch border. He used part of his grant money from the federal research ministry to pay for a nightwatchman to guard his crops until harvest.

Scientists have also considered carrying out their field trials in other countries where

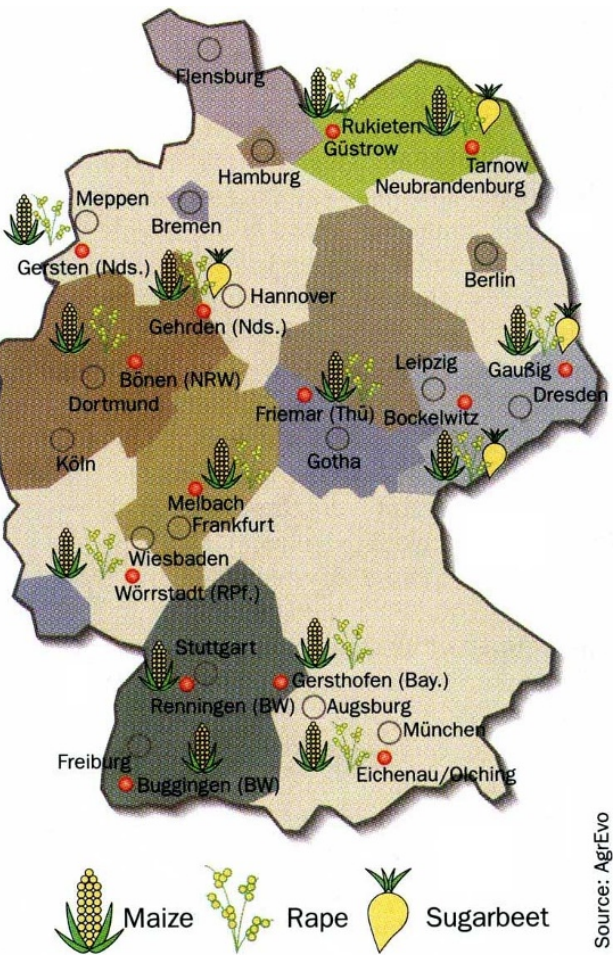

ome sites of open-air experiments with genetically odified crops in Germany.

they are less likely to be attacked. But this has not proved feasible for various reasons. Lothar Willmitzer, director of the Max Planck Institute for Molecular Plant Physiology in Golm, near Potsdam, east Germany, says plant geneticists should not abandon their rights to carry out field trials in Germany because of pressure from activists. On a more practical level, he points out, scientists need to be physically near their trials.

But Barsch, who fears his scientific career may suffer if he cannot complete his work, hopes to conduct his 1997 trial in the Netherlands, provided he can obtain a grant from the European Commission; his current grant does not cover trials abroad.

Despite such caution, the pressure group Genetisches Netzwerk launched a campaign last week based on claims that scientists are trying to exploit the situation in east Germany, where economic concerns outweigh radical environmental concerns, by turning more frequently to conducting trials there.

Henning Strodthoff, a spokesman for the group, says that "the choice of sites with the lowest potential for protest shows that [scientists] feel they can exploit the economic difficulties of people".

Most of the applications are from commercial companies needing to show that their tests crops can be grown safely in local conditions in order to market the crops in Germany in the future, and have been encouraged by last year's relaxation of genetic release laws, reducing the bureaucratic burden of preparing trials.
Alison Abbott 